\title{
Obecny stan i perspektywy wykorzystania Linii Hutniczej Szerokotorowei w Polsce
}

\section{Current state and perspectives for using the Broad Gauge Metallurgy Line in Poland}

Streszczenie: Transport kolejowy w Polsce odgrywa ważną rolę w gospodarce. Dotyczy to zarówno przewozów pasażerskich, jak również i towarowych. Od lat prowadzi się procesy modernizacyjne zarówno infrastruktury kolejowej, jak i taboru w kolejnictwie. Spośród wielu elementów infrastruktury kolejowej warto poddać analizie wywołującą wiele dyskusji Linię Hutniczą Szerokotorową. Celem niniejszej publikacji jest wykazanie, że Linia Hutnicza Szerokotorowa może posiadać korzystne perspektywy dalszego rozwoju w transporcie międzynarodowym. Hipoteza badawcza opiera się na przesłankach wskazujących istotne znaczenie omawianej linii dla gospodarki. W pracy dokonano omówienia genezy Linii Hutniczej Szerokotorowej w czasach gospodarki centralnie sterowanej. Omówiono także aktualną sytuację gospodarczą spółki zarządzającej omawianą linią kolejową poprzez przedstawienie jej kluczowych wskaźników ekonomicznych. Szczególną uwagę poświęcono scharakteryzowaniu możliwych perspektyw rozwoju Linii Hutniczej Szerokotorowej, biorąc pod uwagę aktualne uwarunkowania ekonomiczne. Artykuł powstał przy wykorzystaniu materiałów zwartych, informacji netograficznych oraz danych statystycznych. Metodę badawczą zastosowaną w publikacji stanowi analiza danych zastanych. Wyniki badań pozytywnie weryfikują postawioną tezę.

\begin{abstract}
Rail transport in Poland plays an important role in the economy. This applies to both passenger and freight transport. For years, modernisation processes have been carried out for both the railway infrastructure and the rolling stock in the railway sector. Among the many elements of the railway infrastructure, it is worth analysing the Broad Gauge Metallurgy Line, which prompts numerous discussions. The purpose of this publication is to show that the Broad Gauge Metallurgy Line may have favourable prospects for further development in international transport. The research hypothesis is based on the indicated importance of the discussed line for the economy. The paper discusses the roots of the Broad Gauge Metallurgy Line in the times of centrally-controlled economy. The current economic situation of the company managing the railway line in question was also discussed by presenting its key economic indicators. Particular attention was paid to the possible prospects for the development of the Broad Gauge Metallurgy Line, taking into account the current economic conditions.The article was created with the use of compact materials, netographic information and statistical data. The research method used in the publication is the analysis of existing data. The results of the research positively verify the thesis.
\end{abstract}

Słowa kluczowe: Cargo; infrastruktura kolejowa; rozwój; transport międzynarodowy 
Keywords: Cargo; development; international transport; railway infrastructure

Otrzymano: 9 grudnia 2020

Received: 9 December 2020

Zaakceptowano: 13 lutego 2021

Accepted: 13 February 2021

Sugerowana cytacja/ Suggested citation:

Sala, K. (2021). Obecny stan i perspektywy wykorzystania Linii Hutniczej Szerokotorowej w Polsce. Prace Komisji Geografii Przemysłu Polskiego Towarzystwa Geograficznego, 35(1), 85-95. doi: 10.24917/20801653.351.6

\section{WSTĘP}

Linia Hutnicza Szerokotorowa to jedna z największych inwestycji okresu PRL. Wykorzystywana intensywnie od początków swojego istnienia, po przemianach ustrojowych zaczęła podlegać wpływom zmiennej koniunktury.

Korzyści wynikające z wykorzystywania transportu kolejowego na dłuższych dystansach bez potrzeby przeładunku wpływają korzystnie na perspektywiczne wykorzystanie LHS w zakresie przewozów towarowych.

Celem niniejszej publikacji jest wykazanie, że LHS posiada korzystne perspektywy dalszego rozwoju w zakresie dalekobieżnego transportu międzynarodowego. W pracy dokonano omówienia początków LHS, jej rozwoju oraz bieżącej sytuacji. Wskazano na jego konkurencyjność w stosunku do innych rodzajów transportu. Hipoteza badawcza opiera się na przesłankach wskazujących istotne znaczenie omawianej linii dla gospodarki.

Artykuł powstał przy wykorzystaniu publikacji zwartych, źródeł internetowych oraz branżowych danych statystycznych. Metodę badawczą zastosowaną w publikacji stanowi analiza danych zastanych. Wyniki badań pozytywnie weryfikują postawioną tezę.

\section{RYS HISTORYCZNY LHS}

Linia Hutnicza Szerokotorowa (linia kolejowa nr 65), zwana dawniej Linią Hutniczo-Siarkową (LHS) to niezelektryfikowana, jednotorowa linia kolejowa przebiegająca od kolejowego przejścia granicznego w Hrubieszowie do stacji Sławków Południowy LHS (Ciemnoczułowski, 2009).

Linia kolejowa nr 65 jest najdłuższą szerokotorową linią kolejową w Polsce i jednocześnie w Europie Środkowej. Jej długość od granicy państwa do końcowej stacji towarowej w Sławkowie wynosi około 395 kilometrów. Łączna długość torów na linii wynosi około 524 kilometry. Jest powszechnie uważana za najdalej wysuniętą na zachód Europy linię o rozstawie toru 1520 mm (Malinowski, 2006).

Koncepcja budowy pojawiła się już w latach 20. XX wieku. Jej pierwotnym przeznaczeniem był transport węgla kamiennego wewnątrz terytorium ówczesnej Rzeczypospolitej Polskiej - z polskiej części Górnego Śląska na obszar Wołynia. Innym celem była chęć zagęszczenia sieci kolejowej w południowej części dawnego zaboru rosyjskiego, na którego terytorium infrastruktura kolejowa była bardzo słabo rozwinięta. Ostatecznie inwestycja nie została wówczas zrealizowana i na wiele lat zarzucona (Linia kolejowa, 2020). 
Kolejny raz impulsem do realizacji pierwotnych pomysłów stał się rozwój przemysłu ciężkiego w Polsce, w tym budowa sztandarowej inwestycji PRL, czyli Huty Katowice (Kunicki, Ławecki, 2018). Brak rodzimych zasobów rudy żelaza wymuszał jej import z ZSRR. Wykorzystywana do tej pory linia kolejowa Medyka-Jaworzno-Szczakowa okazała się niewystarczająca dla potrzeb rosnącego importu surowca. Dodatkowo odmienny rozstaw szyn wymuszał konieczność pracochłonnego i kosztownego przeładunku. Polskie Koleje Państwowe (PKP) stanęły przed wyborem pomiędzy modernizacją istniejącej linii, a budową nowego połączenia kolejowego. Ostatecznie zdecydowano się na drugie rozwiązanie. LHS została wybudowana w latach 1976-1979 wg projektu inż. Józefa Skorupskiego (Z kart historii LHS - część 1, 2020).

Linia kolejowa nr 65 obok Centralnej Magistrali Kolejowej była największym przedsięwzięciem kolejowym Polskich Kolei Państwowych w okresie Polskiej Rzeczypospolitej Ludowej (Lijewski, 1986). Posiadała znaczenie strategiczne związane z ewentualnym umożliwieniem szybkiego transportu wojsk i sprzętu z ZSRR na zachód. Od samego początku inwestycja wywoływała jednak skrajne emocje. Jej przeciwnicy wykazywali zagrożenie dla cennych przyrodniczo obszarów Roztoczańskiego Parku Narodowego, Puszczy Sandomierskiej oraz większe uzależnienie polityczno-gospodarcze od wschodniego sąsiada (Eisler, 1992).

Nowa linia charakteryzowała się na całej długości rosyjskim szerokim rozstawem szyn $(1520 \mathrm{~mm})$, brakiem elektryfikacji oraz ograniczeniem prędkości do $80 \mathrm{~km} / \mathrm{h}$. Jej realizacja umożliwiała wygodny, ciągły transport rudy żelaza, przy jednoczesnej możliwości wywozu krajowego węgla kamiennego i siarki do ZSRR. Zarówno elementy infrastruktury (np. szyny), jak i taboru pochodziły z ZSRR (Domański, Ożóg, 1977).

Budowa linii miała wymiar propagandowy i angażowała, oprócz robotników kolejowych, licznych przedstawicieli wojska, OHP, a także uczniów i studentów. Przy jej realizacji korzystano nierzadko z najnowocześniejszych rozwiązań technicznych. Linia została zaopatrzona także na całej swej długości w terminale przeładunkowe, usprawniające jej wykorzystanie. W celu obniżenia kosztów przedsięwzięcia przyjęto koncepcję budownictwa kolejowego o charakterze zunifikowanym i zintegrowanym. Inwestycja spowodowała rozwój infrastruktury kolejowej w Olkuszu, Hrubieszowie, a także w Zamościu i Sędziszowie. Powstały także nowe miejsca pracy dla mieszkańców terenów tranzytowych (Z kart historii LHS - część 2..., 2020).

Niestety nie wszystkie plany udało się zrealizować. Linia do dnia dzisiejszego nie została zelektryfikowana, co stanowi jej największy mankament. Nie zbudowano również obiecywanej obwodnicy Roztoczańskiego Parku Narodowego. Planowane jako obiekty tymczasowe kontenerowe nastawnie przetrwały w dużym stopniu do dziś (Mazur, 2005).

Od 1979 roku zarząd nad linią przejęły, wyodrębnione według terytorialnego podziału specjalnego, Wschodnia i Śląska Dyrekcja Okręgowych Kolei Państwowych, natomiast od roku 1997 zarządzanie LHS przejął Zakład Eksploatacji Linii Hutniczo-Siarkowej (Malinowski, 2011).

Od 1979 roku do końca lat 80. XX wieku linia była intensywnie użytkowana do przewozów towarowych. Sytuacja uległa zmianie na początku lat 90. XX wieku. W związku ze zmianami w polityce gospodarczej transport surowców uległ znaczącemu ograniczeniu. W roku 1994 zaprzestano przewozów siarki. LHS zaczęła przeżywać kryzys przewozowy. Pojawiła się wówczas koncepcja wykorzystywania LHS do przewozów pasażerskich. 
Przez całe lata 90. XX wieku LHS była wykorzystywana do dalekobieżnych przewozów pasażerskich do Rosji i na Ukrainę. Początkowo była to trasa Olkusz-Moskwa. W 1993 roku ofertę rozszerzono o trasę Lwów-Zamość Północny i trasę Moskwa-Zamość Północny. W 1994 roku pojawiła się trasa Olkusz-Charków. Od połowy lat 90. XX wieku pociągi jeździły już jednak sporadycznie. Sytuację LHS utrudniały częste zmiany zarządców spółki oraz niesymetryczne jej wykorzystanie (przewaga importu nad eksportem).

Linia LHS nie jest jedyną szerokotorową linią kolejową w Europie Środkowej. Linia kolejowa ŠRT (Użhorod-Haniska pri Košicach) na Słowacji to zelektryfikowane połączenie o podobnych parametrach i znaczeniu jak LHS (Kubáček, 1999). Biorąc jednak pod uwagę możliwości i plany jej dalszej rozbudowy do Wiednia w Austrii, mogłaby stanowić istotną konkurencję dla LSH (Idea širokorozchodnej trate žije, 2008).

\section{WSPÓŁCZESNY STAN LHS}

Od początków XXI wieku sytuacja Linii Hutniczej Szerokotorowej bywała zmienna. Od 2000 roku w ramach reorganizacji PKP powołano spółkę PKP Linia Hutnicza Szerokotorowa Sp. z o.o. z siedzibą w Zamościu (LHS, 2020). Takie działania miały usprawnić funkcjonowanie LHS i zwiększyć sprawność zarządzania. Nowa spółka pozostaje do dnia dzisiejszego całkowicie w rękach Skarbu Państwa. Podejmowane wcześniej próby prywatyzacji spółki nie zostały sfinalizowane ze względu na sprzeciw związków zawodowych (Malinowski, 2006).

Od 2001 roku ponownie zmienił się charakter użytkowania linii kolejowej LHS. Linia zaczęła mieć na powrót charakter wyłącznie towarowy, obsługując przy tym tylko przewozy międzynarodowe. W celu otrzymania wiarygodnego obrazu kondycji gospodarczej spółki zarządzającej linią kolejową nr 65 należy omówić kluczowe wskaźniki takie jak zatrudnienie, poziom zysków (strat) netto oraz wielkość przewozów (Żukowski, 2010).

Obecnie LHS należy do największych przewoźników towarowych w Polsce, obok PKP Cargo, DB Cargo Polska Lotos Kolej oraz CHL Logistics. Analizę bieżącej sytuacji spółki PKP LHS Sp. z o.o. warto zacząć od przeglądu liczby pracowników. Liczbę pracowników spółki w latach 2004-2018 przedstawia tabela 1. Analiza danych w niej zawartych wskazuje na niewielkie wahania w zakresie liczby osób zatrudnionych w spółce w rozpatrywanym okresie. Zatrudnienie w roku 2018 w porównaniu do 2005 wskazuje na przyrost na poziomie około 13\%. Generalnie można uznać, że zatrudnienie w spółce w rozpatrywanym okresie było stabilne.

W następnej kolejności warto wziąć pod uwagę wyniki finansowe omawianej spółki. Dane dotyczące zysku netto PKP LHS Sp. z o.o. w latach 2004-2018 przedstawia rycina 1 . Dane zawarte na tej rycinie 1 wskazują na znaczne wahania w zakresie zysków netto osiąganych przez spółkę w omawianym okresie. W przeciwieństwie do zatrudnienia, świadczy to wyraźnie o dużej zmienności sytuacji finansowej firmy. Przyczyn takiego stanu rzeczy należy upatrywać w ogólnej sytuacji gospodarczej w kraju i na świecie.

Kolejny wskaźnik warty omówienia stanowi majątek przedsiębiorstwa. Wartość rzeczowych aktywów trwałych PKP LHS Sp. z o.o. prezentuje tabela 2. Analiza danych w niej zawartych wskazuje, że wartość rzeczowych aktywów trwałych spółki PKP LHS wahała się w przedziale pomiędzy około 450 a około $550 \mathrm{mln}$ zł. W omawianym okresie wartość majątku firmy można uznać za stosunkowo stabilną. 
Tabela 1. Liczba pracowników PKP LHS Sp. z o.o. w latach 2004-2018

\begin{tabular}{|c|c|}
\hline Rok & Liczba pracowników \\
\hline 2004 & 1186 \\
\hline 2005 & 1165 \\
\hline 2006 & 1247 \\
\hline 2007 & 1237 \\
\hline 2008 & 1265 \\
\hline 2009 & 1219 \\
\hline 2010 & 1263 \\
\hline 2011 & 1270 \\
\hline 2012 & 1283 \\
\hline 2013 & 1247 \\
\hline 2014 & 1292 \\
\hline 2015 & 1263 \\
\hline 2016 & 1307 \\
\hline 2017 & 1283 \\
\hline 2018 & 1314 \\
\hline
\end{tabular}

Źródło: opracowanie własne na podstawie raportów rocznych Grupy PKP

Rycina 1. Zysk netto PKP LHS Sp. z o.o. w latach 2004-2018

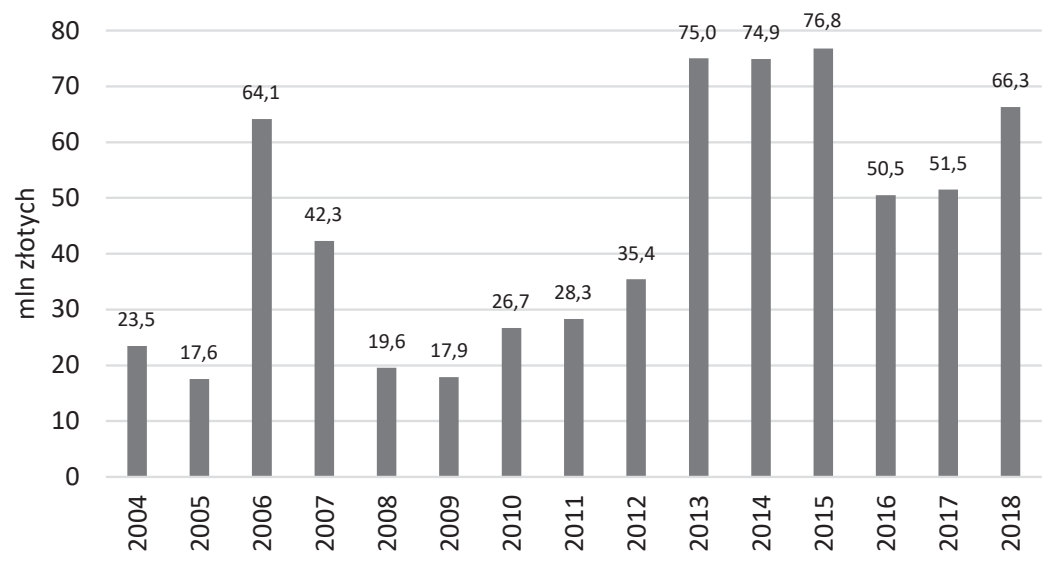

Źródło: opracowanie własne na podstawie raportów rocznych Grupy PKP

Tabela 2. Wartość rzeczowych aktywów trwałych PKP LHS Sp. z o.o. w latach 2012-2018

\begin{tabular}{|c|c|}
\hline Rok & $\begin{array}{c}\text { Wartość rzeczowych aktywów } \\
\text { trwałych w mln złotych }\end{array}$ \\
\hline 2012 & 500,9 \\
\hline 2013 & 510,9 \\
\hline 2014 & 501,3 \\
\hline 2015 & 478,6 \\
\hline 2016 & 450,3 \\
\hline 2017 & 500,6 \\
\hline 2018 & 554,9 \\
\hline
\end{tabular}

Źródło: opracowanie własne na podstawie raportów rocznych Grupy PKP 
Analizie warto poddać również wielkość przewozów spółki. Dane dotyczące wielkości przewozów PKP LHS Sp. z o.o. w latach 2004-2018 przedstawia rycina 2.

Rycina 2. Wielkości przewozów PKP LHS Sp. z o.o. w latach 2004-2018

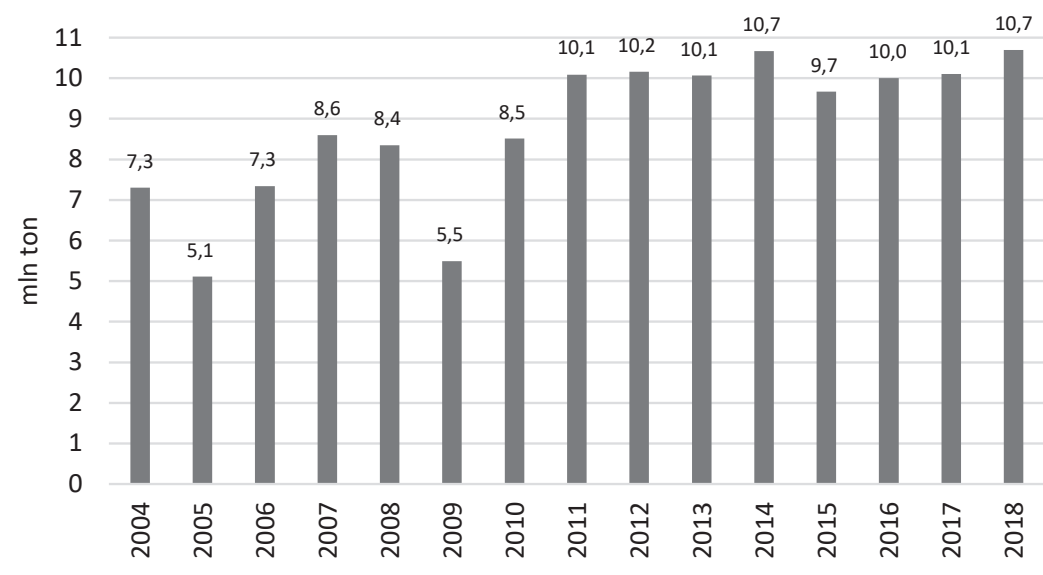

Źródło: opracowanie własne na podstawie raportów rocznych Grupy PKP

Analiza danych zawartych na wykresie 2 pozwala stwierdzić, że wielkości przewozów spółki PKP LHS podlegały wahaniom od 2004 do 2010 roku. Natomiast od 2011 roku utrzymują się na porównywalnym co roku poziomie, co należy uznać za korzystne. Niewątpliwie wpływ na ten stan rzeczy miała sytuacja gospodarcza.

Biorąc pod uwagę strukturę przewożonych przez PKP LHS towarów, największy udział ma w niej ruda żelaza (ponad 50\%). Do innych przewożonych towarów należą: węgiel kamienny i brunatny, wyroby petrochemiczne, surowce mineralne oraz drewno.

Kolejny wskaźnik określający znaczenie omawianej spółki stanowi jej rynkowy udział w krajowym rynku przewozów towarowych pod względem udziału w masie towarów i wykonanej pracy przewozowej. Wskaźniki przedstawiono w tabeli 3.

Tabela 3. Udział PKP LHS Sp. z o.o. w krajowym rynku przewozów towarowych w latach 2011-2018

\begin{tabular}{|c|c|c|c|c|}
\hline \multirow{2}{*}{ Rok } & \multicolumn{2}{|c|}{ Przewieziona masa towarów } & \multicolumn{2}{c|}{ Wykonana praca przewozowa } \\
\cline { 2 - 5 } & $\begin{array}{c}\text { Udział w rynku } \\
\text { w \% }\end{array}$ & Miejsce & $\begin{array}{c}\text { Udział w rynku } \\
\text { w \% }\end{array}$ & Miejsce \\
\hline 2011 & 4,05 & 5 & 5,99 & 5 \\
\hline 2012 & 4,39 & 5 & 6,82 & 3 \\
\hline 2013 & 4,32 & 4 & 6,62 & 3 \\
\hline 2014 & 4,66 & 3 & 7,06 & 3 \\
\hline 2015 & 4,30 & 4 & 6,24 & 3 \\
\hline 2016 & 4,48 & 4 & 6,58 & 3 \\
\hline 2017 & 4,28 & 4 & 4,20 & 3 \\
\hline 2018 & 5,69 & 4 & 5,69 & 3 \\
\hline
\end{tabular}

Źródło: opracowanie własne na podstawie danych Departamentu Regulacji Rynku Kolejowego, Wydział Analiz: Przewozy towarowe 
Udział spółki PKP LHS w krajowym rynku przewozów towarowych według przewiezionej masy towarów kształtował się w okresie od 2011 do 2018 roku na poziomie około 4-5\%, natomiast udział przewoźnika według wykonanej pracy przewozowej wyniósł w analogicznym okresie około 6-7\%. Pod względem udziału w krajowym rynku przewozów towarowych omawiana spółka zajmuje od lat czołowe miejsca (spośród 20 największych przewoźników), ustępując m.in. spółkom PKP Cargo czy Lotos Kolej (Lotos Kolej, 2020).

\section{PERSPEKTYWY ROZWOJU LHS}

Omawiając perspektywy rozwoju LHS w przyszłości należy wziąć pod uwagę następujące uwarunkowania:

- konieczność modernizacji i unowocześnienia infrastruktury i taboru;

- rozwój kontaktów handlowych wschód-zachód;

- konkurencyjność transportu kolejowego, szczególnie w stosunku do transportu morskiego, lotniczego i drogowego.

Linia Hutnicza Szerokotorowa funkcjonuje ponad 40 lat i nie należy już do najnowocześniejszych. W dalszym ciągu do obsługi składów wykorzystywane są energochłonne i ciężkie lokomotywy spalinowe, podlegające jednak procesom modernizacyjnym. Aby sprostać wymogom nowoczesnego transportu w zakresie szybkości przewozów, bezpieczeństwa, a przede wszystkim optymalizacji kosztów konieczne jest podejmowanie systematycznych nakładów inwestycyjnych.

Z myślą o dalszym rozwoju, w ciągu ostatnich lat PKP LHS zainwestowały ponad 200 mln zł. Łącznie do końca roku 2025 spółka zamierza zainwestować 800 mln zł. Celem tych inwestycji jest zwiększenie przepustowości, poprawa bezpieczeństwa oraz zmniejszenie zużycia paliwa. Władze spółki LHS zapowiedziały również pełną komputeryzację linii do 2024 roku, co wydatnie przyczyni się do usprawnienia jej obsługi (Tracichleb: Do 2024..., 2020).

Poprawie interoperacyjności LHS mogłoby służyć szersze wykorzystanie systemu automatycznej zmiany rozstawu kół z rozstawu szerokotorowego na normalnotorowy i odwrotnie, czyli SUV 2000. Wykorzystanie tego nowatorskiego rozwiązania włączyłoby skutecznie LHS do systemu kolei normalnotorowych Europy i umożliwiło osiąganie większych korzyści w skali z przewozów (Zestaw przestawny..., 2006).

Poważnie rozważany jest także pomysł wydłużenia linii LHS ze Sławkowa do portów rzecznych w Gliwicach i Kędzierzynie-Koźlu. Takie rozwiązanie umożliwiłoby bezpośredni dostęp do Odrzańskiej Drogi Wodnej, a poprzez nią do dróg wodnych Niemiec i innych krajów zachodnioeuropejskich. Perspektywa transportu kombinowanego (kolejowo-wodnego) bez koniczności korzystania z zatłoczonych dróg kołowych mogłaby znacząco podnieść atrakcyjność linii LHS (Madrjas, 2019).

Wartym odnotowania jest także fakt powołania 16 czerwca 2020 roku spółki córki PKP LHS - PKP Linia Chełmska Szerokotorowa Sp. z o.o., która ma zarządzać istniejącą linią szerokotorową Dorohusk-Chełm. Może to w przyszłości zaowocować wybudowaniem połączenia szerokotorowego do Włodawy i Zawady a tym samym do istniejącej linii LHS (O krok bliżej do..., 2020).

Ważnym wyzwaniem dla przyszłości LHS będzie również elektryfikacja całej linii. Działanie to mogłoby przynieść znaczące korzyści ekonomiczne, jak i ekologiczne. Jej przeprowadzenie będzie jednak uzależnione od wyników analizy opłacalności 
zastosowania systemu zasilania rozpowszechnionego w Polsce ( $3 \mathrm{kV}$ prądu stałego) czy też systemu ukraińskiego (2,5KV prądu zmiennego) (Rojek, 2012). Zastosowanie elektryfikacji podniosłoby również konkurencyjność linii w stosunku do słowackiego ŠRT (Clurysek, 2017).

Kolejne perspektywy rozwoju LHS są związane bezpośrednio z realnymi szansami wymiany handlowej z sąsiadami ze wschodu, a także z krajami azjatyckimi. LHS jako najdalej wysunięta na zachód linia szerokotorowa w Europie stwarza możliwości perspektywicznego przewozu w osi wschód-zachód. Poprzez szerokotorowy system kolei ukraińskich posiada bezpośredni dostęp do kolei wszystkich krajów WNP, magistrali transsyberyjskiej oraz do Chin przez Kazachstan (Nowym Jedwabnym Szlakiem). Szeroki tor umożliwia także bezpośredni dostęp bez przeładunków do takich krajów jak Mongolia. Szans na rozwój LHS należałoby upatrywać w intensyfikacji handlu na linii UE-Chiny, a także z krajami WNP.

Ważnym wydarzeniem w historii Linii Hutniczo Szerokotorowej był przyjazd do Polski pociągu kontenerowego z Chin 5 stycznia 2020 roku. Trasę z chińskiego Xi'an do Sławkowa o długości 9477 km skład przebył w ciągu 12 dni (Pierwszy pociąg z Chin..., 2020). Pociąg przebył drogę wykorzystując transkaspijską trasę TMTM. Przewożony ładunek został przeładowany na końcowej stacji i dostarczony do finalnych odbiorców. Kolejny skład z Chin przybył do Polski 1 lutego 2020 roku (Pociag kontenerowy..., 2020).

Powyższe wydarzenia dowodzą, że znaczenie LHS nie musi się ograniczać wyłącznie do współpracy z krajami WNP, jak początkowo planowano. Chiny są obecnie największym eksporterem na świecie i jednym z najważniejszych partnerów handlowych krajów Unii Europejskiej. Należy przypuszczać, że przyjazd pierwszych składów z Chin będzie stanowić początek intensyfikacji handlu międzynarodowego z partnerami dalekowschodnimi. Władze spółki LHS planują zintensyfikować ruch do poziomu kilkuset pociągów rocznie. Obecnie jednak, zwłaszcza w sytuacji światowej pandemii, trudno jest prognozować przyszłość LHS w transporcie towarów z Dalekiego Wschodu.

Przyszłość omawianej linii kolejowej należy także rozpatrywać pod względem jej konkurencyjności w stosunku do transportu morskiego, lotniczego, a także drogowego. Porównanie czasu transportu w przypadku wybranych rodzajów środków transportowych z Chin do Polski prezentuje tabela 4.

Tabela 4. Czas transportu w przypadku wybranych środków transportowych z Chin do Polski przy uwzględnieniu procedur celnych i dowozów do odbiorcy

\begin{tabular}{|l|c|}
\hline \multicolumn{1}{|c|}{ Rodzaj środka transportu } & Orientacyjny czas transportu \\
\hline Lotniczy & $4-7 \mathrm{dni}$ \\
\hline Kolejowy & $11-14 \mathrm{dni}$ \\
\hline Morski & $28-49 \mathrm{dni}$ \\
\hline
\end{tabular}

Źródło: opracowanie własne na podstawie: Ile trwa import... (2020)

Dane zawarte w tabeli 4 wskazują, że transport kolejowy może stanowić istotną konkurencję pod względem czasowym w stosunku do transportu morskiego. Kolejnym istotnym czynnikiem, który należy poddać analizie, są koszty transportu zestawione w tabeli 5. Dane wskazują na niewielkie różnice kosztów pomiędzy transportem morskim a kolejowym. Dodatkowo transport morski generuje dodatkowe, znaczące zagrożenia:

- ekologiczne (dla powietrza, wody, brzegów morskich); 
Tabela 5. Porównanie kosztów transportu morskiego i kolejowego z Chin do Polski na podstawie trzech rodzajów ładunków

\begin{tabular}{|l|l|}
\hline \multicolumn{1}{|c|}{ Transport kolejowy } & \multicolumn{1}{c|}{ Transport morski } \\
\hline $\begin{array}{l}\text { Waga do } 1000 \mathrm{~kg} \text {. Objętość: 4,0 CBM. Miejsce } \\
\text { nadania: Shenzhen. Miejsce odbioru: Wrocław. Cena: } \\
\text { 755 USD. W tym ubezpieczenie i odprawa }\end{array}$ & $\begin{array}{l}\text { Waga do 1000 kg. Objętość: 4,0 CBM. Miejsce } \\
\text { nadania: Shenzhen. Miejsce odbioru: Wrocław. } \\
\text { Cena: 695 USD. W tym ubezpieczenie i odprawa } \\
\text { Transport do magazynu dodatkowo 250 USD) }\end{array}$ \\
\hline $\begin{array}{l}\text { Waga do 3000 kg. Objętość: 9,0 CBM. Miejsce } \\
\text { nadania: Shenzhen. Miejsce odbioru: Wrocław. Cena: } \\
\text { 1260 USD. W tym ubezpieczenie i odprawa }\end{array}$ & $\begin{array}{l}\text { Waga do 3000 kg. Objętość: 9,0 CBM. Miejsce } \\
\text { nadania: Shenzhen. Miejsce odbioru: Wrocław. Cena: } \\
\text { 1100 USD. W tym ubezpieczenie i odprawa }\end{array}$ \\
\hline $\begin{array}{l}\text { Waga do 3000 kg. Objętość: 12,5 CBM. Miejsce } \\
\text { nadania: Shenzhen. Miejsce odbioru: Wrocław. Cena: } \\
\text { 1565 USD. W tym ubezpieczenie i odprawa }\end{array}$ & $\begin{array}{l}\text { Waga do 3000 kg. Objętość: 12,5 CBM. Miejsce } \\
\text { nadania: Shenzhen. Miejsce odbioru: Wrocław. Cena: } \\
\text { 1275 USD. W tym ubezpieczenie i odprawa }\end{array}$ \\
\hline
\end{tabular}

Źródło: opracowanie własne na podstawie: Porównanie cen transportu... (2020).

- zdrowotne i dla życia (dla licznych członków załogi);

- dla ładunków, statków i infrastruktury portowej (katastrofy morskie, kolizje, piractwo morskie itp.).

Transport lotniczy w porównaniu do kolejowego jest zdecydowanie szybszy. Jednak biorąc pod uwagę oddalenie lotnisk od typowych miejsc docelowych, czas transportu ulega wydłużeniu. Ponadto niekorzystne warunki atmosferyczne mogą powodować dodatkowe opóźnienia. Należy także mieć na uwadze wyższe koszty transportu, ograniczone możliwości załadunkowe i konieczność spełnienia kryteriów transportowych przez towar.

Przewaga transportu kolejowego nad drogowym polega przede wszystkim na jego znacznie mniejszej szkodliwości dla środowiska przyrodniczego, większego bezpieczeństwa, a także możliwości odciążenia autostrad i innych dróg od intensywnego ruchu pojazdów ciężarowych.

Omawiając względy ekologiczne warto wspomnieć, że już teraz w niektórych krajach rozpatruje się możliwość elektryfikacji autostrad z myślą o ograniczeniu emisji $\mathrm{CO}_{2}$ (Elektryczna autostrada..., 2019).

Rozwój transportu kolejowego (w tym LHS) może przyczynić się do ograniczenia tego problemu, a także do zmniejszenia zatłoczenia dróg oraz liczby wypadków drogowych.

Do innych zalet LHS, które warunkują jej przyszłość, zaliczyć można:

- możliwość transportu różnego typu ładunków (masowe, drobnicowe, kontenerowe, ponadnormatywne);

- możliwość obniżenia kosztów transportu poprzez intermodalność;

- możliwość prowadzenia najdłuższych pociągów kontenerowych w Europie o długości do $950 \mathrm{~m}$;

- obecność węzła logistycznego w Sławkowie z dostępem do stałych połączeń z wielkimi terminalami załadunkowymi w Gdańsku, Swarzędzu, Maddaloni we Włoszech oraz Schwarzheide w Niemczech;

- lokalizacja wzdłuż przebiegu linii terminali przeładunkowych z możliwością rozładunku różnego rodzaju towarów.

Atrakcyjność położenia i przebiegu LHS, zwłaszcza na terenie Roztocza mogłaby przyczynić się do rozwoju turystycznych przewozów pasażerskich. 


\section{ZAKOŃCZENIE}

Budowa Linii Hutniczej Szerokotorowej to z pewnością jedno z największych osiągnięć w powojennej historii polskiego kolejnictwa. Niewątpliwie należy wykorzystywać jej bieżący potencjał w zakresie transportu międzynarodowego. Dotyczy to w szczególności połączeń z dalekowschodnimi partnerami, nie zapominając przy tym o współpracy z sąsiadami (Ukraina, Rosja). Jednocześnie warto pamiętać o jej perspektywach rozwoju, dokonując niezbędnych modernizacji. Unowocześnienie omawianej linii (zwłaszcza elektryfikacja), jak również jej ewentualne przedłużenie mogłoby jeszcze bardziej poprawić jej konkurencyjność.

Przyszłość LHS będzie jednak zależeć także od czynników niezależnych bezpośrednio od kolei. Wymienić tutaj należy sytuację polityczno-gospodarczą na świecie (m.in. rozwijanie dobrosąsiedzkich stosunków Polski z sąsiadami ze wschodu oraz kontrahentami z krajów zachodnich) czy rozwój handlu z dalekowschodnimi partnerami (współpraca polskich firm z podmiotami chińskimi). Dotyczy to głównie przewozów towarowych. Służyć temu może intensyfikacja działań lobbingowych na rzecz kolei.

\section{Literatura \\ References}

Ciemnoczułowski, T. (2009). Szerokim torem LHS. Łódź: Dom Wydawniczy Księży Młyn.

Clurysek, A. (2017, 13 grudnia). Do 2025 roku LHS podwoi inwestycje do wartości 800 milionów złotych. Kurier Zamojski. Pozyskano z https://www.kurierzamojski.pl/do-2025-roku-lhs-podwoi-inwestycje-do-wartosci-800-milionow-zlotych/ (dostęp 20.04.2020).

Domański, E., Ożóg, Z. (1977). Lokomotywy spalinowe serii ST44. Warszawa: Wydawnictwa Komunikacji i Łączności.

Eisler, J. (1992). Zarys dziejów politycznych Polski 1944-1989. Łódź: BGW.

Elektryczna autostrada startuje w Niemczech. (2019, 5 sierpnia). Pozyskano z https://www.dw. $\mathrm{com} / \mathrm{pl} /$ elektryczna-autostrada-startuje-w-niemczech/a-48653445 (dostęp 02.07.2020).

Idea širokorozchodnej trate žije. (2008, 4 kwietnia). Pozyskano z https://ekonomika.sme. sk/c/3811869/idea-sirokorozchodnej-trate-zije.html (dostęp 15.03.2020).

Ile trwa import statkiem, pociagiem i samolotem z Chin? (2020, 10 czerwca). Pozyskano z https:// fullbax.pl/czas-transportu-z-chin/

Kubáček, J. (1999). Dejiny železníc na území Slovenska. Bratislava: Železnice Slovenskej Republiky.

Kunicki, K., Ławecki, T. (2018). Budujemy drugq Polskę. Wielkie inwestycje PRL-u. Łódź: Dom Wydawniczy Księży Młyn.

LHS. PKP Linia Hutnicza Szerokotorowa Sp. z o.o. (2020, 5 czerwca). Pozyskano z https://lhs. com.pl/pl

Lijewski, T. (1986). Geografia transportu Polski. Warszawa: Państwowe Wydawnictwo Ekonomiczne.

Linia kolejowa. (2020, 13 kwietnia). Pozyskano z http://www.jura-pilica.com/?linia-kolejowa, 411

Lotos Kolej. (2020, 30 maja). Pozyskano z https://www.lotoskolej.pl/

Madrjas, J. (2019, 30 marca). Pozyskano z https://www.rynekinfrastruktury.pl/wiadomosci/kolej/szeroki-tor-az-do-portu-srodladowego-byly-minister-ma-wizjonerski-plan-57182.html

Malinowski, Ł. (2006). MCL Sławków. Rynek Kolejowy, 4.

Malinowski, Ł. (2011). 10 lat PKP LHS. Rynek Kolejowy, 7, 8-11.

Mazur, A. (2005). 25 lat LHS. Świat Kolei, 5.

O krok bliżej do uruchomienia Linii Chełmskiej Szerokotorowej. (2020, 17 czerwca). Pozyskano z https://lhs.com.pl/pl/wydarzenia/521

Pierwszy pociąg $z$ Chin dotarł do Polski bez przeładunku na granicy UE. Przejechał Nowym Jedwabnym Szlakiem. (2020, 4 lutego). Pozyskano z https://next.gazeta.pl/ 
next/7,151003,25569114,pierwszy-pociag-z-chin-dotarl-do-polski-bez-przeladunku-na-granicy.html\#s=BoxOpMT

PKP. (2020, 2 marca). Raport finansowy. Pozyskano z https://www.pkp.pl/pl/raport-finansowy Pociag kontenerowy z Chin po LHS. (2020, 3 lutego). http://www.lhs.pl/conowego.lhs (dostęp 10.08.2020).

Porównanie cen transportu morskiego z kolejowym. Ile kosztuje? Jak długo trwa taki transport? (2020, 11 sierpnia). Pozyskano z https://www.mountainbusiness.eu/post/por\%C3\%B3wnanie-cen-transportu-morskiego-z-kolejowym-ile-kosztuje-jak-d\%C5\%82ugo-trwa-taki-transport

Rojek, A. (2012). Zasilanie trakcji elektrycznej w systemie prądu stałego 3 kV. Warszawa: Kolejowa Oficyna Wydawnicza.

Tracichleb: Do 2024 LHS będzie w pełni skomputeryzowana. (2020, 5 lutego). Rynek Kolejowy. Pozyskano z https://www.rynek-kolejowy.pl/wiadomosci/tracichleb-do-2024-lhs-bedzie-w-pelni-skomputeryzowana-95388.html (dostęp 23.05.2020).

Urząd Transportu Kolejowego. (2020, 12 lipca). Statystyka przewozów towarowych. Kolejowe przewozy towarowe $w$ Polsce. Zestawienie roczne $w$ latach 2000-2019. Pozyskano z https://www.utk.gov.pl/pl/raporty-i-analizy/analizy-i-monitoring/statystyka-przewozow-to/15773,Dane-podstawowe.html

Z kart historii LHS - część 1. (2020, 4 kwietnia). Pozyskano z http://www.lhs.pl/info/historia-cz1 Z kart historii LHS - część 2. Trochę teraźniejszości. (2010, 16 kwietnia). Pozyskano z http://www. lhs.pl/info/historia-cz2

Zestaw przestawny SUW 2000. (2006, 24 sierpnia). Pozyskano z http://archive.is/cUIdV (dostęp 02.02.2020).

Żukowski, Z. (2010, 17 lutego). LHS linia szerokotorowa szansq dla polskich przedsiębiorców. Pozyskano z https://forsal.pl/nieruchomosci/aktualnosci/artykuly/7660606,lhs-linia-szerokotorowa-szansa-dla-polskich-przedsiebiorcow.html (dostęp 12.04.2020).

Krzysztof Sala, dr, adiunkt, Uniwersytet Pedagogiczny w Krakowie, Wydział Politologii, Instytut Prawa i Ekonomii, Katedra Przedsiębiorczości i Innowacji Społecznych. Absolwent Międzynarodowych Stosunków Gospodarczych (specjalność Studia Europejskie) na Uniwersytecie Ekonomicznym w Krakowie (studia magisterskie) zakończonych dyplomem, podyplomowych studiów w zakresie zarządzania jakością i ochroną środowiska w Wyższej Szkole Zarządzania i Bankowości w Krakowie oraz Kolegium Zarządzania i Finansów Szkoły Głównej Handlowej w Warszawie, zakończone uzyskaniem tytułu doktora nauk ekonomicznych. Wieloletnie doświadczenie w praktyce gospodarczej na różnych stanowiskach zawodowych, w tym stanowiskach menedżerskich. Doświadczenie w pracy naukowo-dydaktycznej zdobyte na uczelniach publicznych i prywatnych. Udział jako trener w szkoleniach finansowanych z UE w ramach programu „Kapitał Ludzki”. Do głównych obszarów zainteresowań zalicza politykę gospodarczą i turystyczną Polski i Unii Europejskiej, przedsiębiorczość w sektorze małych i średnich firm oraz zarządzanie strategiczne.

Krzysztof Sala, PhD, research assistant, Pedagogical University of Krakow, Institute of Law and Economy, Department of Entrepreneurship and Social Innovation. A graduate of International Economic Relations (specialisation in European Studies) at the Cracow University of Economics (MA degree), post-graduate studies in the field of quality management and environmental protection at the School of Management and Banking in Krakow and the College of Management and Finance School of Economics in Warsaw, leading to a doctoral degree in economic sciences. He has experience in business practice, including on managerial positions, as well as in scientific and teaching work gained at public and private institutions. He participated as a coach in training funded by the EU under the Human Capital Programme. The main areas of interest include economic policy and tourism in Poland and the European Union, entrepreneurship in small and medium-sized businesses, and strategic management.

ORCID: https://orcid.org/000-0002-7614-9309

\section{Adres/address:}

Uniwersytet Pedagogiczny w Krakowie

Instytut Prawa i Ekonomii

ul. Podchorążych 2

30-084 Kraków

e-mail: krzysztof.sala@up.krakow.pl 